\title{
NACIONALISMO Y OTREDAD. LAS PERSONIFICACIONES DE CASTILLA Y GALICIA EN CATALUÑA (1880-1936) ${ }^{1}$
}

\author{
Carlos Reyero \\ Universidad Autónoma de Madrid
}

\begin{abstract}
RESUMEN
Este artículo muestra como las personificaciones alegóricas de Castilla y Galicia fueron utilizadas para impulsar visualmente el nacionalismo catalán. Por lo tanto, se convirtieron en instrumento de una estrategia donde la imagen tuvo un gran impacto para fijar identidades y para intervenir en procesos políticos. La cultura del 'doble patriotismo' había promovido y alentado una equiparación entre lo catalán y lo castellano. Pero enseguida se interpretó la oposición de Castilla a este modelo: la castellanización de España desencadenó una reacción satírica contra aquella dueña. La implicación de las mujeres refleja visiones conflictivas entre Castilla y Cataluña. Galicia emerge como una muchacha joven, a la que Cataluña guía y asesora en el camino de la autonomía y el autogobierno. En realidad, sirve para ilustrar nuevas formas de relación.
\end{abstract}

Palabras clave: Nacionalismo, Género, Identidad nacional, Alegoría política, España, Cataluña, Castilla, Galicia

\section{ABSTRACT}

This article details how allegorical personifications of Castile and Galicia were used to boost Catalan nationalism in a visual sense and became the instrument of a political strategy in which the image had significant impact in establishing identities and intervening in political processes. The culture of 'dual patriotism' promoted and encouraged equality between what is Catalonian and what is Castillian, though Castile was seen as being opposed to such a model, with the promotion of Castillian values in Spain triggering a satirical reaction to her as an authoritarian figure. The involvement of women reflects the conflict in visions between Castile and Catalonia, with Galicia emerging as a young girl whom Catalonia guides and advises on the path towards self-government, all of which serves to illustrate new forms of relationships.

Keywords: nationalism, gender, national identity, political allegory, Spain, Catalonia, Castile, Galicia

La construcción visual del nacionalismo se ha alimentado de una interpretación sesgada del pasado, una manipulación de ciertos referentes antropológicos y un uso convencional de determinados valores simbólicos. En general, se tiende a juzgar como un imaginario estable -no solo mental sino también visual- concebido para afianzar una pertenencia grupal, permanente y abstracta, a partir de la cual se interpreta el mundo propio y el de los demás, desde unos orígenes remotos hasta la eternidad.

Pero, "el aura de la nacionalidad opera siempre en el seno de unos determinados contextos de poder"2. Si el poder es una fuerza dinámi- ca, la expresión de la nacionalidad no puede ser nunca estable y cerrada. A veces, ni siquiera excluyente, sobre todo si colisiona con estrategias políticas circunstanciales o con procesos legitimadores de nuevos poderes presentados como nacionales, que pretenden ganar adeptos. Además, no debe olvidarse que "la pertenencia a una comunidad nacional no es ahora, ni lo era en el pasado, la única dimensión operativa y condicionadora en la vida social" 3 .

Sin embargo, el proyecto nacional y sus fundamentos ha sido tradicionalmente una cuestión vertebral del debate político. La encarnación de la identidad en una figura alegórica, que tiene en 
Marianne su caracterización más prototípica ${ }^{4}$, es un testimonio bien significativo de su dimensión sagrada. Esta diosa nacional francesa posee sus pares, más o menos relacionadas con ella o con unos orígenes comparables, en otros lugares, también en España, donde funcionaron simultáneamente tanto personificaciones de la nación española como de los antiguos reinos, principados, provincias o ciudades ${ }^{5}$. El valor nacional que se otorgó a estas alegorías depende de la época y de los contextos en que fueron utilizadas.

En Cataluña, y en el periodo que nos ocupa, se aprecia una peculiar metamorfosis en su uso, relacionada tanto con estrategias cambiantes de las élites de poder como con la importancia que los distintos grupos sociales dieron a la (re)presentación visual de la(s) patria(s). Por lo tanto, su personificación se ajusta a propuestas políticas concretas, por más que lo nacional tienda a exhibirse como un punto de encuentro alejado de cualquier conflicto. No deja de resultar curiosa esa versatilidad de la alegoría patriótica, cuando ésta había sido concebida en origen como un referente de unidad interclasista e intergeneracional, por encima de toda controversia. En realidad, se aprovecha lo que la personificación encierra visualmente de incontestable (determinada idea de España o de Cataluña, benéfica para toda la sociedad, catalana y/o española), aunque desde la conciencia de que se trata de un ejercicio de propaganda cuyo objetivo está pendiente de ser alcanzado, por lo que, en última instancia, resulta conflictivo.

Esta aparente contradicción entre las características del lenguaje visual alegórico y su uso circunstancial tiene que ver con el medio más habitual donde se encuentran las personificaciones, los periódicos ilustrados ${ }^{6}$ y, en particular, las publicaciones satíricas ${ }^{7}$. La prensa ha sido reconocida como uno de los instrumentos fundamentales en la reproducción de la nacionalidad $^{8}$. Pero su poder de socialización nunca es uniforme. La caricatura, además, carece de lo que se ha denominado "fijeza semántica": su significado no queda completamente cerrado, sino que actúa como un elemento mediador de otro mensaje que está más allá de ella9. Por otra parte, cualquier imagen -y especialmente las que tienen que ver con el arte público- está sometida a un proceso de permanente resemantización. Su contenido narrativo originario puede ser incluso irrelevante cuando esa imagen se reubica en la memoria al lado de otras ${ }^{10}$.

La personificación funciona, pues, como una metáfora visual versátil, que evoca el dinamismo de la acción política. En consecuencia, ha de ser tratada como una imagen nacional sui generis, en tanto que, por su partidismo, no es equiparable al resto de figuraciones intangibles del nacionalismo. Esta dimensión metafórica simplifica el mensaje: no es posible detectar en ella todos los matices que poseen los discursos nacionalistas. Pero, por lo mismo, es útil para condensar ideas genéricas e interiorizarlas. Como ha señalado $\mathrm{E}$. Ucelay, "la progresiva intensificación de la dinámica comunicativa a partir de la tecnificación del siglo XIX ha facilitado el abuso de la metáfora, hasta convertir su ejercicio en el banal consumismo de imágenes verbales y visuales entrecruzadas", pero esclarecedoras como "medio para la comprensión del mito y su significado"11.

En ese sentido, la forma que adopta la personificación -por lo general mujer que responde a comportamientos asociados al género, la cultura, el modo de vida o la procedencia territorial, según patrones codificados y convencionales- tiene consecuencias en la percepción que se termina por proyectar sobre un grupo nacional en relación con otro, como categoría apriorística sobre las que ha de basarse cualquier vínculo. La visualización de la identidad propia, a través de un individuo que actúa como en la vida, es esencial para el reconocimiento de una conciencia diferenciada comparable: consolida la posición ante otro, siempre definido desde un nosotros. En la medida que la personificación también encierra una ideología de clase y de género, lo nacional funciona como elemento legitimador (o eventualmente deslegitimador, según la perspectiva). Por eso, ejemplifica actitudes que encierran significados en la percepción y en el aprendizaje del nacionalismo, mucho más mediatizado por componentes ideológicos de lo que una percepción superficial de las imágenes pudiera llevar a pensar ${ }^{12}$.

La dualidad ha constituido una forma habitual en la presentación de realidades territoriales diferentes, con objeto de evocar algún tipo de 
nexo entre ellas, ya desde el Antiguo Régimen: la patria de origen de la esposa de un rey, por ejemplo, con motivo de su matrimonio o su fallecimiento, o la celebración triunfal del poder monárquico en una determinada ciudad son algunas de las circunstancias en las que se visualiza una coexistencia armónica de lugares patrios mediante la alegoría. Evidentemente, en unos casos, esta relación es de equivalencia y en otros de subordinación. Pero lo relevante es la existencia de una tradición visual heredada donde la pertenencia importa.

Esta tradición se intensifica a partir de las guerras napoleónicas, la formación de los estados-nación y, sobre todo, la propaganda visual de las relaciones políticas y culturales internacionales. En España, la guerra contra los franceses produjo curiosas imágenes fraternales de la alianza militar entre Hispania y Britania, como se sabe. Pero la personificación dual fue más allá de estrategias concretas, como en el conocido cuadro de J.F. Overbeck, Italia y Germania (1828, Munich, Neue Pinakothek), cuando esas denominaciones ni siquiera respondían a estados. En la prensa satírica esta forma de comprensión del mundo se visualiza pronto ${ }^{13}$. La cultura de masas, a través de la prensa, la tarjeta postal, el cartel y el merchandising de grandes eventos, así como las campañas de imagen de los partidos políticos, se convirtió, ya a comienzos del siglo XX en el cauce principal de estas personificaciones ${ }^{14}$.

El lenguaje de la dualidad patriótica no ha de verse, por tanto, como una peculiaridad catalana. "La España del siglo XIX -como muchos otros lugares de Europa- se caracterizaba por la presencia de patriotismos 'duales' o incluso 'múltiples', de acuerdo con los cuales las identidades locales o regionales reforzaban las nacionales" 15 . La necesidad de conciliar -o de enfrentar- sentimientos de pertenencia ha producido tanto imágenes de unidad como de exclusión, de dualidad o de pluralidad de identidades, que tienen matices muy distintos según el autor que las concibe, el lugar en el que se difunden y los destinatarios a los que se dirigen. De todos modos, entre el último cuarto del siglo XIX y el primer tercio del $X X$, Cataluña fue un territorio especialmente fértil en imágenes que aludían a la(s) identidad(es) nacional(es). La forma más evidente a través de la que se hace ostentación visual de esa(s) identidad(es) es la personificación patriótica, aunque puede detectarse en otras formas de arte público. Los matices de ese dualismo fueron allí muy cambiantes, con unos intereses cada vez más reacios a aceptar una identidad simplemente subsumida en otra.

La elección de las personificaciones de Castilla y Galicia en su relación con Cataluña, justo en el momento de eclosión del nacionalismo, no es arbitraria. Desde luego no fueron las únicas alegorías que entonces visualizaron las relaciones entre Cataluña y otros lugares. Nos encontramos con varios y diferentes imaginarios de relaciones entre territorios, no siempre en términos duales ni equivalentes: no es igual el vínculo que se establece con Valencia o Baleares que con Andalucía o el País Vasco, ni por supuesto con España o con otras ciudades, regiones o países extranjeros ${ }^{16}$. En ese sentido, Castilla y Galicia representan dos modelos opuestos y paradigmáticos de la vieja y la nueva España que se imagina desde Cataluña: Castilla es la antigua dueña de una patria uniforme que el nacionalismo quiere cambiar y Galicia es la joven autonomía que ha de aprender de Cataluña.

\section{Castilla y Cataluña}

Para dar forma a la "adhesión a dos artefactos patrióticos [...] distintos y de reciente aparición en la escena social del siglo XIX" en Cataluña, como eran "el patriotismo político nacido en Cádiz", por un lado, y "las recreaciones de una identidad catalana", por otro, Fradera acuñó el término de "doble patriotismo"17. El término expresa, pues, sentimientos de pertenencia a una comunidad y de identidad política, que alcanzaron su apogeo durante el Sexenio Revolucionario. Aunque los discursos nacionalistas terminarían por modificar aquel entramado, el catalanismo burgués conservador mantuvo los gestos de esa dualidad: "Queremos ser una de tantas estrellas de la bandera de España", dijo Frederic Soler en $1890^{18}$.

Hasta finales del siglo XIX no hubo "proyectos nacionalistas catalanes en oposición al español", sino "lecturas catalanas, eso sí, del proyecto nacional español", todas las cuales se movieron "en el espacio del doble patriotismo", 
incluyendo "la afirmación del orgullo catalán por parte de sus sustentadores" 19 . Ese orgullo incluía también la expresión del dolor por los males de España, imaginario que contaba con una larga tradición visual ${ }^{20}$. En publicaciones satíricas, republicanas y anticlericales, publicadas en catalán, como La Campana de Gracia o La Tramonta$n a^{21}$ todavía es frecuente encontrar, en el último cuarto de siglo, representaciones de la España castellana como matrona apesadumbrada, a la que acechan todos los males. Aunque viste túnica orlada de castillos y leones, que evocan la versión simplificada del antiguo escudo utilizado hasta la época de Isabel II, con las armas de Castilla y León exclusivamente, en ella reconocen los catalanes una patria propia. Así se aprecia, entre otros ejemplos, en una ilustración de La Tramontana titulada ¡Pobre España!22 (Fig. 1), donde el edificio de la Universidad de Barcelona aparece como un simbólico contrapunto de sabiduría catalana, de seny, frente a una barbarie de políticos, militares y clero, a los que todavía no se identifica con una patria rival ni diferente.
Sin embargo, el doble patriotismo en Cataluña, más que expresarse a través de una relación de subordinación unitaria, tiende a formularse a través de realidades territoriales diferenciadas, aunque complementarias. Esta circunstancia implica una distinción de lo castellano, que se había asimilado a lo español, de lo propiamente catalán. Se configura así lo castellano como lo otro, lo no catalán, aunque no tiene necesariamente que ver con lo que significaba Castilla entonces como región, ni exactamente con lo que había significado históricamente como Corona. Es un recurso de contraste para reivindicar lo catalán como específico dentro de lo español.

A lo largo de los años ochenta del siglo XIX se aprecian varias presentaciones públicas de este discurso que hubieron de contribuir, sin duda, a consolidar ese imaginario. Veamos algunas de ellas.

En 1884 se inaugura en Vilanova y la Geltrú la Biblioteca y Museo Víctor Balaguer cuyo papel como reivindicador e ideólogo de una dualidad

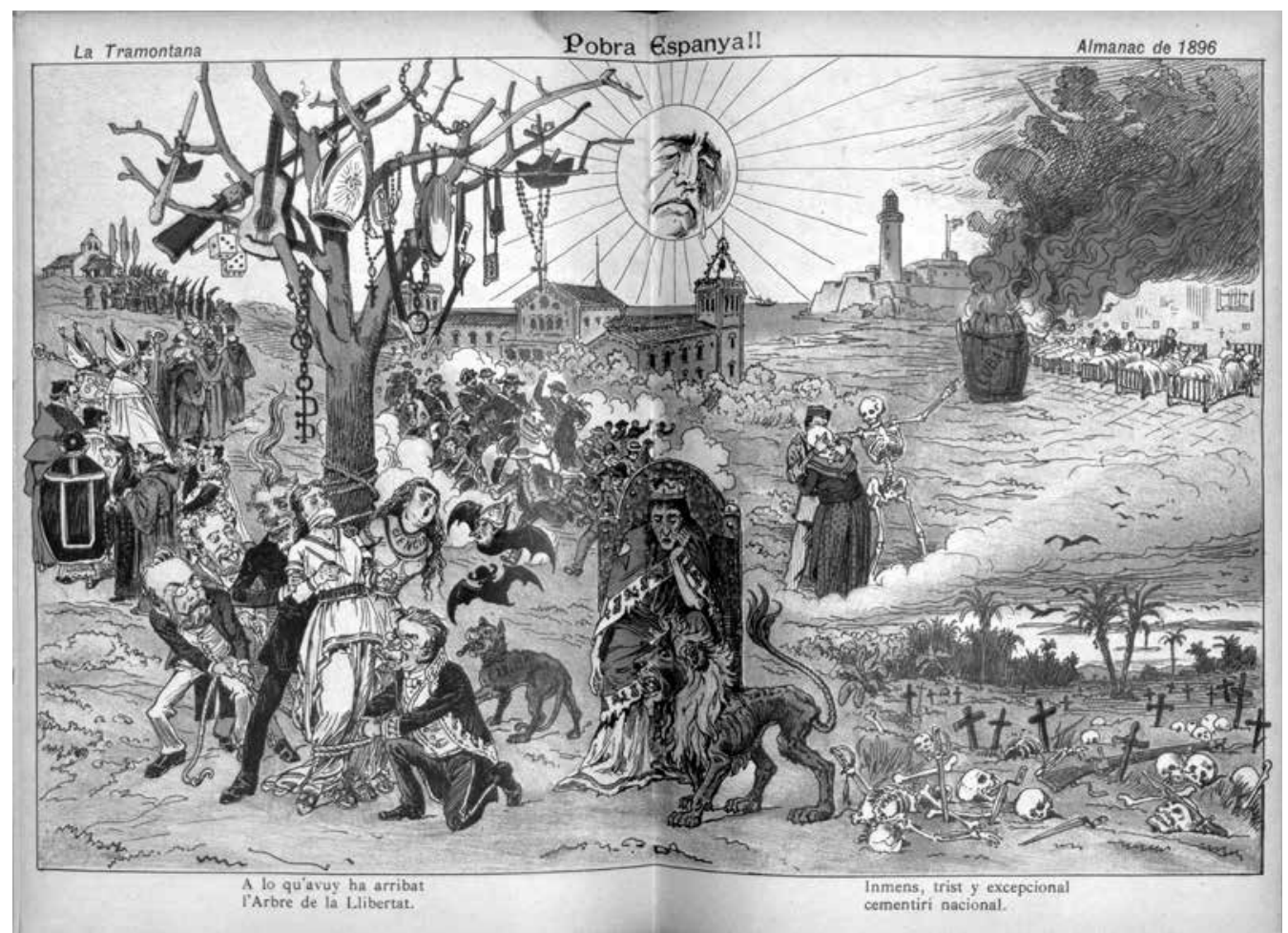

Fig. 1. ¡Pobre España!, Almanac de la Tramontana, 1896. 
nacional es bien conocido: "llaman nacionalidad a las cosas de Castilla, como si Castilla fuera España"23. Balaguer trató de reconfigurar la antigua unión dinástica colocando las glorias de la Corona de Aragón y, específicamente, de Cataluña en una posición central. La condición de masón de Balaguer debió de ser determinante en el dualismo simbólico del edificio vilanoven$\mathrm{se}^{24}$, que arranca de la misma naturaleza de la institución, concebida como biblioteca y como museo. La construcción fue decorada con esgrafiados alusivos a esa doble función que recorren su exterior, según idea del maestro de obras que lo construyó, Jeroni Granell i Mundet, dibujados por Josep Mirabent ${ }^{25}$. En la elección de las figuras representadas hay una dualidad evidente entre escritores y artistas, acorde con las obras que guarda -libros y obras de arte- y su doble papel en el imaginario del progreso. Pero aquí interesa destacar la expresión de una dualidad inherente a la cultura nacional que alberga el templo, al combinar figuras de una historia castellana y de una historia catalana, tal y como se aprecia en los nombres que aparecen a la izquierda de la entrada -Ausias March, Garcilaso, Desclot, Cervantes- y a la derecha Velázquez, Berruguete, Campeny, Juan de Herrera.

Uno de los ejemplos en los que con mas claridad se visualiza ese dualismo cultural castellanocatalán es a través de las dos estatuas elegidas para flanquear la fachada del taller Masriera ${ }^{26}$, en la calle Bailén de Barcelona, una dedicada a Eduardo Rosales y la otra a Marià Fortuny. La idea de que Rosales y Fortuny representaban lo mejor del arte español del siglo XIX se empezó a configurar desde el mismo momento de su fallecimiento. El hecho de que las dos vidas se truncaran tempranamente, y con poco más de un año de diferencia, favoreció los paralelismos entre trayectorias artísticas bien dispares. Son conocidas las palabras del discurso del pintor catalán Francesc Sans, cuando ingresó en la Academia de San Fernando de Madrid: "Sigamos con fe y entusiasmo [...] el noble ejemplo de los malogrados Fortuny y Rosales, que solo por el arte y para el arte vivieron: así honraremos su memoria; así cumpliremos con la patria y con la humanidad"27. Con motivo de la inauguración del edificio en 1884, la prensa elogia el espíritu desinteresado de los Masriera, que no pertenecen al número de esos pintores que se limitan a pintar buenos cuadros y a invertir sus productos en títulos del 4 por 100 o en tierras de pan llevar, como pudiera un mercader gallego, sea dicho sin ofensa de los laboriosos y honrados hijos de Galicia. Nuestros paisanos Masriera rinden ferviente culto al arte que profesan; y como todo culto necesita un templo [...].

Ahi están en su ancho vestibulo, las estatuas de Fortuny y de Rosales, nuestros dos grandes pintores contemporáneos, de pie sobre el pedestal de su gloria y destellando rayos de ella en el interior de este santuario del arte $^{28}$.

Bien significativo resulta ya que aparezca el nombre de Galicia con un cierto menosprecio, que trata de corregirse. Algunas semanas después vuelven a ensalzarse "estas dos estatuas que adornan la fachada del Taller Masriera, representando las dos figuras más celebradas de la pintura moderna española, [...] debidas al cincel del distinguido escultor señor Reynés, que las ha modelado de una manera bien entendida, teniendo en cuenta la colocación que se les había de dar y a la importancia que tienen, ocupando los lugares más salientes, a los lados de la fachada principal" 29. La presencia de Rosales junto a Fortuny no impidió a Carles Pirozzini calificar la paleta de José Masriera como "siempre catalana" 30 .

Este emparejamiento pervive todavía en una ilustración publicada en L'Esquella de la Torratxa en 1898 (Fig. 2). En ella, Rosales y Fortuny llevan maniatadas a las integrantes de una coIla modernista, camino de su encierro, como si fuera una cuerda de presas bajo su vigilancia. Calificada de "irónicamente antimodernista"31,

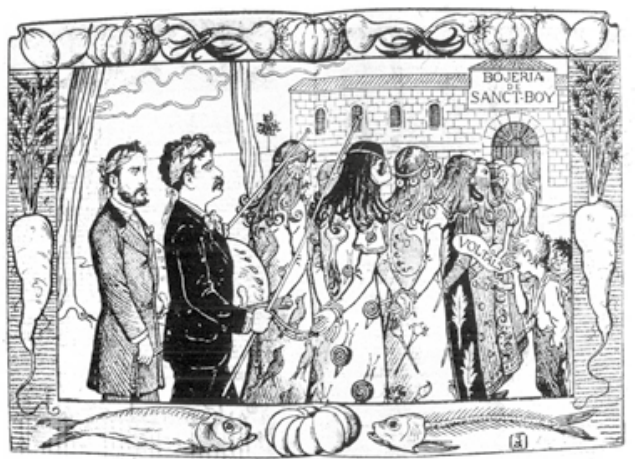

Fig. 2. Manel Moliné i Muns, La pandilla modernista. L'Esquella de la Torratxa, 1898. 
la imagen parece reivindicar a los viejos pintores de la España dual como representantes de un arte serio, frente a las veleidades estéticas de una burguesía urbana y cosmopolita, que una revista popular como L'Esquella debió de mirar entonces con recelo.

Sin duda el testimonio más elocuente de la dualidad castellano-catalana que conforma la idea de España en el imaginario catalán del fin de siglo es el monumento a Colón de Barcelona, inaugurado en 1888. Como señalé en otro lugar ${ }^{32}$, la relevancia que se otorga en él a las cuatro personificaciones alegóricas de Cataluña, Aragón, Castilla y León, que se encarga de potenciar la prensa ilustrada ${ }^{33}$ (Fig. 3), sirve para poner en paralelo Cataluña y Aragón con Castilla y León como artífices del imperialismo hispano. En última instancia, se destaca el papel específico de Cataluña, frente a Aragón, y

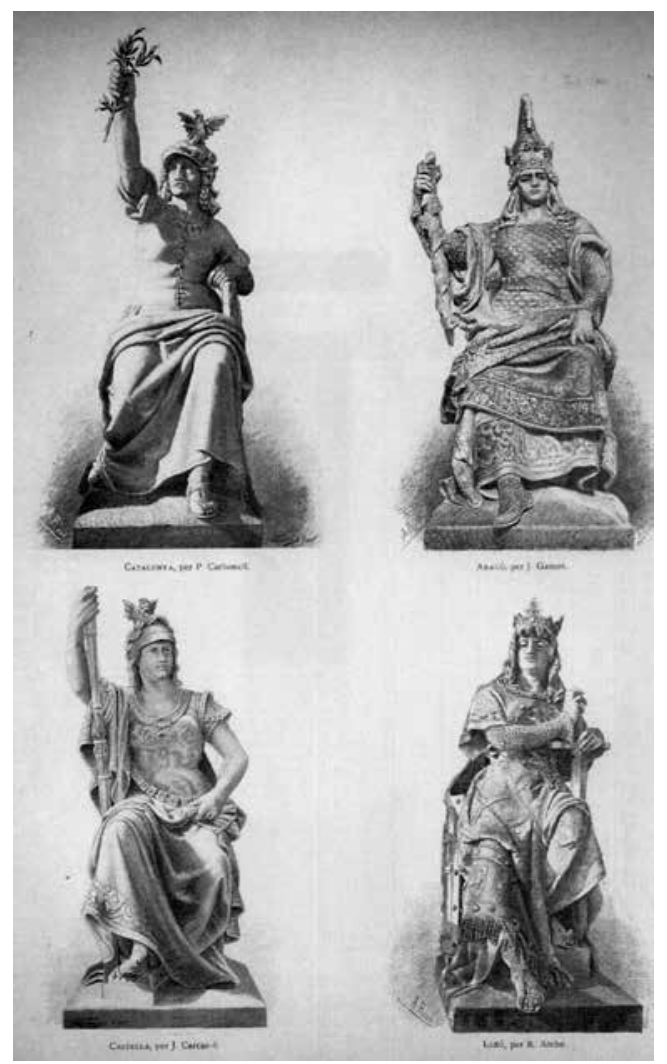

Fig. 3. Personificaciones del monumento a Colón de Barcelona: Cataluña (P. Carbonell), Aragón (J. Gamot), Castilla (J. Clarasó) y León (R. Atché), La llustració Catalana, 1892. queda así colocada a la par que Castilla, que ya había desplazado a León en la prelación de títulos de la Corona española, pero a ningún otro antiguo reino se alude. En ese mismo sentido, se ha constatado el deseo del catalanismo por buscar una correspondencia entre la doble corona de Austria y Hungría, de donde procedía la Reina Regente, María Cristina de Habsburgo, con una eventual "división de Coronas 'real y condal', España-Cataluña, en el Homenaje a la Regente de 1888 y las Bases de Manresa de 1892" 34 .

En el ámbito de la imagen satírica este imaginario dual pervive en revistas de carácter izquierdista federal como La Campana de Gracia. Con ocasión del temporal que sufrieron algunas zonas de España la noche del día 15 de enero de 1898, que afectó especialmente a Barcelona, con el desbordamiento de los ríos Besós y Llobregat, la mencionada publicación acusa al gobierno de no hacer nada por aliviar la situación de los damnificados, que son las clases populares, mientras la burguesía barcelonesa hacía ejercicios espirituales: "Ni a pesar de la gran lluvia de las nubes, cesará por eso la lluvia trimestral de las contribuciones y tributos de todas clases", dice el cronista. Incluye en portada una ilustración titulada Lloviendo sobre mojado (Fig. 4), con el siguiente pie: "Vaya, esto ya parece la liquidación final". En ella se ve a unos tipos populares que se refugian en el tejado de una vivienda, a punto de ser cubierta por las aguas, junto a las personificaciones alegóricas de Cataluña y Castilla, que comparten la situación de indigencia ${ }^{35}$.

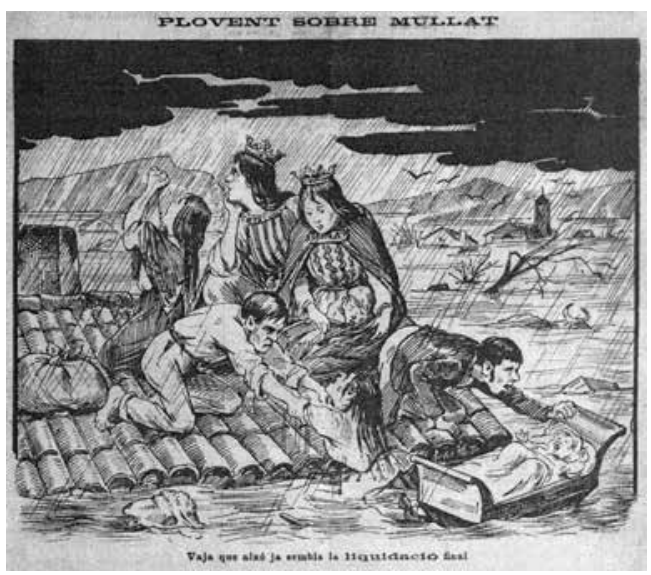

Fig. 4. Lloviendo sobre mojado, La Campana de Gracia, 1898. 


\section{Castilla frente a Cataluña}

El doble patriotismo no impidió que el discurso anticentralista estuviera muy presente en todas las manifestaciones públicas catalanas desde mediados del siglo XIX, con tensiones crecientes $^{36}$. Estas tensiones tuvieron muchas repercusiones visuales. Castilla, convertida en sinécdoque de lo español, empezó a codificarse como un imaginario oscuro y rechazable ${ }^{37}$. Aunque la hispanofobia del catalanismo político ${ }^{38}$ fue visualizada, sobre todo, a través de la animadversión hacia el flamenquismo y el andalucismo, que es un problema distinto, ocasionalmente también aparece denigrado lo castellano, en tanto que monopolizador de lo español ${ }^{39}$.

Así había sucedido ya cuando los republicanos federalistas catalanes habían personificado la forma del estado durante la Primera Repúbli- ca. En una ilustración titulada Las dos republicas (Fig. 5), vemos a la izquierda, "La que quieren los de Madrid": con gesto adusto, mantiene la corona y la capa de armiño, lleva una espada en su mano derecha, es sostenida por el ejército, al fondo, y se apoya sobre una roca en la que está escrito "CENTRALIZACIÓN", debajo de la cual está la vieja España con el escudo de Castilla y León. A la derecha se encuentra "La que quieren los de provincias", inspirada en la Marianne Francesa, que porta una rama de olivo y una tabla con las palabras "LIBERTAD", "IGUALDAD", "FRATERNIDAD" 40 .

Aunque el énfasis en la dualidad castellanocatalana de España, que alimentó el catalanis$\mathrm{mo}^{41}$, limitó mucho las imágenes injuriosas contra Castilla, los teóricos del nacionalismo trasformaron esa dualidad en términos antitéticos,

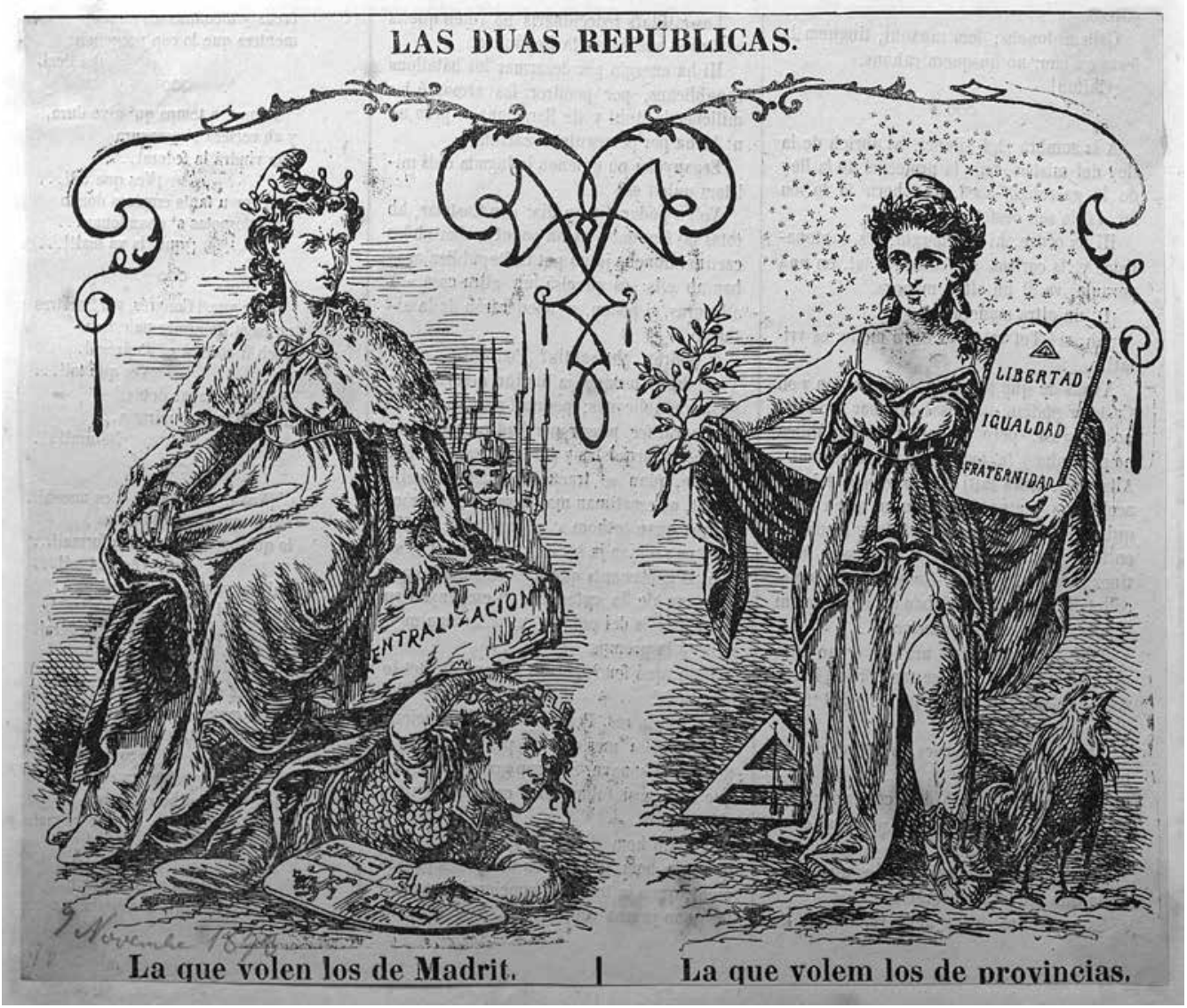

Fig. 5. Tomás Padró i Pedret, Las dos repúblicas, 1873. 
en lugar de complementarios, sin que pueda decirse que hubiera entonces un verdadero interés por pensar Castilla desde Cataluña ${ }^{42}$. A la antigua hegemonía imperial castellana, se oponía el triunfo de la industria y el comercio en la moderna Cataluña, lo que servía para cuestionar si el dominio castellano era capaz de conducir al progreso, al tiempo que se justificaba el papel sustitutivo de Cataluña, como nuevo líder del país ${ }^{43}$. En ese sentido, la propuesta catalanista estaba impulsada por un sentimiento regeneracionista ${ }^{44}$.

La regeneración no solo implicaba la sustitución del objeto del amor patriótico, dirigido ahora a una nueva y auténtica patria, sino también la desnaturalización de la antigua, que ya no merecía el amor. Esta cuestión tiene consecuencias en el imaginario visual y literario de la personificación, en su origen concebida para sugerir afecto $y$, por lo tanto, susceptible también de aludir al desafecto. Si la patria es como una madre, igualmente puede convertirse en madrastra. En ese sentido, por ejemplo, se ha comparado la idea maternal de la nación en la poesía del irlandés Thomas Moore y en la gallega Rosalía de Castro ${ }^{45}$, donde una auténtica madre que sufre y se sacrifica por sus hijos se contrapone a la madre adoptiva que los desatiende: "Foi a Castilla por pan / e saramagos lle deron; / déronlle fel por bebida / peniñas por alimento"46.

En el caso de Cataluña la desnaturalización se produce desde el momento en que Castilla es percibida como una fuerza de dominio y asimilación, que, en la imagen familiar, se traduce en "distintas variantes doloridas: la esposa se volvía infiel, la hermana, hermanastra deshumanizada, la amiga, falsa [...]. Castilla se imponía y humillaba al otro miembro de la alianza o de la familia"47.

Una de estas personificaciones desnaturalizadas aparece en la portada de la revista satírica Cu-Cut! en 1904 (Fig. 6), con motivo del proyecto de ferrocarril traspirenaico, una aspiración catalana que difícilmente podría llevarse a cabo, a causa de "la proverbial dejadez de los gobiernos centralistas y la sistemática dilapidación del tesoro del estado"48. Aparece una representación de "la vieja España castellana arruinada, derrochadora y prepotente" ${ }^{49}$, con el escudo de

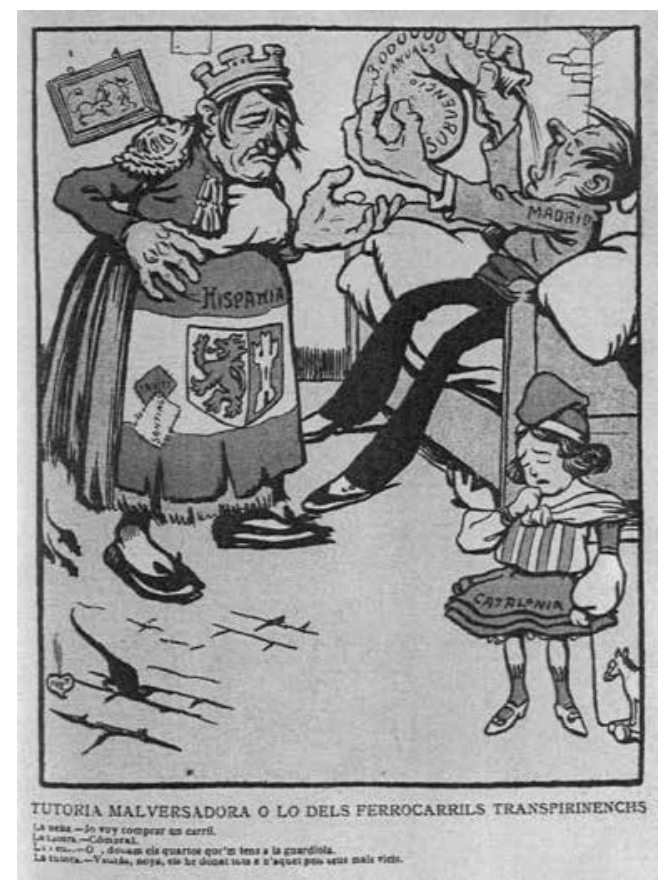

Fig. 6. Gaietà Cornet i Palau, Tutoria malversadora o lo de los ferrocarriles transpirenaicos, Cu-Cut!, 1904.

Castilla y León sobre su raída falda, que lleva los remiendos de Cavite y Santiago. A la izquierda aparece una compungida niña Cataluña, que se dirige a "la tutora" -esa es la nueva posición de la España castellana- reclamándole los cuartos que tiene en la hucha.

Es curioso comparar esa imagen con la que se ofrece de Castilla en otra publicación satírica, Gedeón (Fig. 7), en este caso madrileña. No se vislumbra en ella ninguna asimilación con España en su conjunto, sino una ofensa a su contribución específica, expresada de forma orgullosa y victimista, como suele verse todo nacionalismo a si mismo. Se publica con motivo del discurso pronunciado en el Congreso de los Diputados por Nicolás Salmerón en 1907, entonces diputado de Solidaritat Catalana y, en realidad, defensor de aunar las fuerzas de Cataluña y España. Sin embargo, sus palabras levantaron ampollas en los círculos políticos de la capital española, que se ensañaron con las referidas a Castilla, lo que llevó a los más moderados a clamar por la concordia $^{50}$. En la portada de Gedeón aparece, a la derecha, un avejentado y conspirador Sal- 


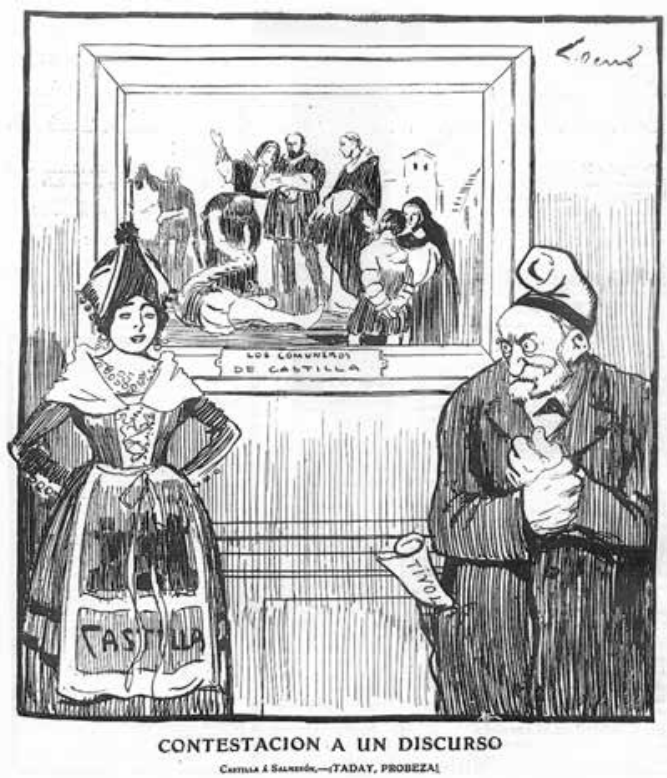

Fig. 7. Pedro Antonio Villahermosa Borao, Sileno, ¡Taday, probeza!, Gedeón, 1907.

merón, con la barretina y un papel en el bolsillo, donde está escrito "TíVOLI", en referencia al teatro barcelonés donde leyó el discurso electoral el 14 de abril de 1907. A la izquierda, como si fuera una referencia abstracta, intemporal e intocable, aparece la personificación de Castilla (en el delantal lleva el nombre y un castillo), situada ante el cuadro de Los Comuneros de Antonio Gisbert y vestida con un traje regional que, por la montera de terciopelo negro, recuerda al de las segovianas. Evidentemente se contrapone la agresividad circunstancial, siniestra y masculina del político catalán a la imperturbabilidad, belleza y feminidad de la personificación de Castilla, recurso muy repetido en el imaginario satírico. Al pie se lee lo que Castilla contesta a Salmerón con displicencia: " ¡Taday, probeza!"51.

\section{Mujer castellana y mujer catalana}

La existencia de un concreto modelo social de mujer es determinante en las relaciones grupales. En los imaginarios nacionalistas, la sublimación de la feminidad, constituye un elemento más de legitimación de su superioridad moral, en tanto que mujer y nación pertenecen a lo ideal, a lo que no se toca ${ }^{52}$. Solo está a disposición la otra, la exótica ${ }^{53}$. El liberalismo se pre- ocupó de integrar a la mujer en la comunidad nacional, hasta el punto de que género e identidad nacional son cuestiones entrelazadas ${ }^{54}$. De hecho, la mujer como argumento poético ligado a los sentimientos que despierta la visualización de la patria es una cuestión tan antigua como extendida ${ }^{55}$.

Por citar un ejemplo catalán, en los Jocs Florals que tuvieron lugar en Lérida en 1899, cuya vinculación con el catalanismo político es bien conocida, fue distinguido un largo poema de Enriqueta Paler i Trullol, dedicado a la mujer catalana, donde se la compara con "la hormiga activa, previsora" y con la abeja. Se destaca su recato, modestia y discreción: "Más que vanidosa disfrutando de fiesta en fiesta le gusta ser del hogar reina y señora". Es "poco expansiva, de aparente aspereza" y tiene "aire majestuoso de soberana". Por supuesto, "madre ejemplar, la más fiel esposa" y "en el cielo del hogar, soberbia estreIla, brilla con esplendor la mujer catalana" 56 .

$\mathrm{Ni}$ que decir tiene que este lenguaje no es privativo de Cataluña. El poema El ama del salmantino Gabriel y Galán dice:

busqué una mujer como mi madre / entre las hijas de mi hidalga tierra [...] / Compartían mis únicos amores / la amante compañera, / la patria idolatrada, I la casa solariega [...] Una sencilla labradora, humilde, / hija de oscura castellana aldea; I una mujer trabajadora, honrada / cristiana, amable, cariñosa y seria / [...] logrolo todo la mujer discreta ${ }^{57}$.

Todo parece indicar que cada cual veía a catalanas y a castellanas de la misma manera, según sus particulares propósitos patrióticos. Pero el nacionalismo no podía dejar de aprovechar este filón. La revista catalanista radical La Tralla dedicaba en 1907 un número extraordinario a las mujeres catalanas, concebido como alegato para animar a su participación en el compromiso político. Un artículo titulado "Dones catalanes", firmado por Martí Julià, presidente de Unió Catalanista, decía que quería para Cataluña

mujeres patricias, mujeres conscientes, mujeres bellas y buenas, mujeres bien mujeres, como van siéndolo cada vez más las mujeres de los pueblos civilizados. El nacionalismo realizará aquella trasformación, por la que será un hecho vuestro ascenso social. Y seréis recatalanizadas y con con- 
ciencia de vuestra misión privada y de vuestros deberes en la sociedad [...] libres de las deficiencias y de la desnaturalización que ahora os hace inferiores ${ }^{58}$

En aquel mismo número se publicaba también un cuento breve, firmado por Elizabeth Malgrat, en el que se narra cómo el señor Pere Malgrat se hace separatista de tot cor, tras su fracasado matrimonio con una castellana. Sus padres ya se oponían diciéndole: "Ya lo verás, muchacho, ella es castellana, tú eres viajante y algún día ¿sabes? Mientras tú estés de viaje tal vez ¿sabes? ¡Es castellana!". Tienen un hijo y la economía del matrimonio pasa por dificultades. Los padres le recuerdan que si no hubiera sido castellana no se hubiera visto tan apurado. Empeña sus escasos bienes y acude a darle dinero a su mujer. Como no le abre, fuerza la puerta, se encuentra al niño llorando abandonado, escucha la voz amenazante de otro hombre en la habitación contigua y exclama: "Suspiraba por mi hijo; y ahora, ahora veo que es el hijo de una castellana!" 59 .

El alboroto causado por esta moraleja fue tal que la revista quedó suspendida, tras publicar el número siguiente, y las reacciones, acaloradas unas, más sensatas otras, se sucedieron, tanto en Madrid como en Barcelona, donde una manifestación destrozó la redacción de La Tralla, antes de dirigirse al ayuntamiento. En la capital, el periodista Eduardo Gómez de Baquero, Andrenio, reconoce que "las ofensas a la mujer son las que más excitan: por ellas se matan los hombres [...] la más floja virilidad siente bullir las violencias del hombre primitivo"60. El Heraldo de Madrid se escandalizaba de "esa tendencia a llamar barraganas a las españolas, a suponerlas capaces del libre concubinato" ${ }^{\prime 61}$. Hubo curiosos textos de desagravio, como un cuento alternativo, firmado por L. de Bellpuig, que ensalzaba la bondad natural de castellanas y catalanas ${ }^{62}$; o el artículo de una catalana orgullosa de serlo, Violeta, que no quería creer que una "señora haya escrito semejante infamia por propio impulso. Es imposible que un corazón de mujer albergue tan crecida cantidad de odio [...] En pluma femenina se impone la moderación [...] ¡Qué depresivo resulta para una mujer hacer patente la debilidad de las demás!"63.

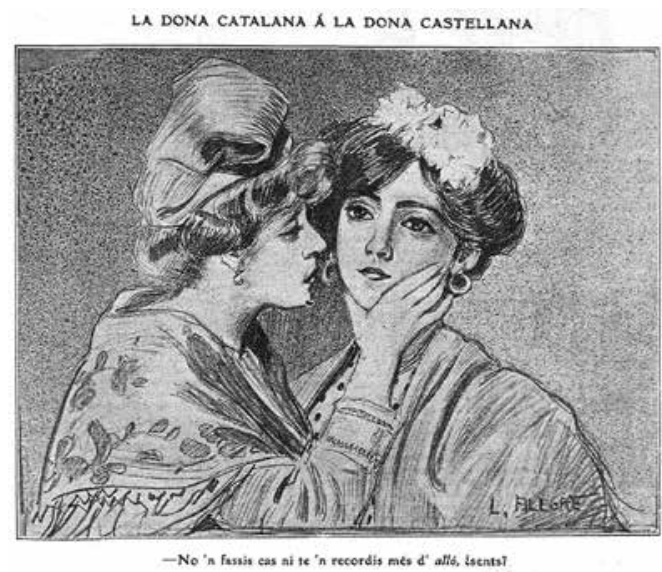

Fig. 8. L. Alegre, La mujer catalana a la mujer castellana, L'Esquella de la Torratxa, 1907

Los periódicos barceloneses quitaron hierro al asunto, incluso la prensa satírica habitualmente hispanofóbica. L'Esquella de la Torratxa expresaba su desacuerdo con el artículo, "ofensivo para las mujeres castellanas"; e incluía un dibujo (Fig. 8) en el que una mujer catalana con barretina acaricia el rostro de una compungida castellana a la que de dice: "No hagas caso ni te acuerdes más de eso, ¿oyes?". De todos modos, ese mismo número se hacía eco de otro libelo contra la mujer catalana, escrito en castellano, en el que se decían cosas de este calibre: "Según declara es modista, pero ya se sabe que hay muchas que dicen tener esta profesión" / "Es una payesa inocente. No está iniciada" / "No se casará más que con catalanistas, porque le gustan todos los hombres"64.

La guerra nacional con munición femenina no se terminó ahí. El iberista catalán Ignasi Ribera i Rovira, que se preocupó por estrechar lazos entre Portugal (a la que incorporaba Galicia, como parte de una misma nación) $)^{65}$ y Cataluña, no le parecía que castellanas y catalanas fueran comparables. En un discurso pronunciado en la Sociedad Geográfica de Lisboa, donde hacía propaganda de la exposición internacional de arte que se preparaba en la Ciudad Condal, "la emprendió -según la prensa madrileña- contra la mujer castellana, a la que declaró inferior a la portuguesa y a la catalana, entre las que halló semejanzas honrosas y aun virtudes de que carece la mujer castellana"66. 
En efecto, los diarios de la capital, que siempre se hacían eco de los insultos contra la patria para descalificar al catalanismo, dieron gran resonancia a unas palabras sacadas del contexto retórico en el que se habían pronunciado: tocar a la mujer propia era lo peor. En La Correspondencia Militar, y bajo el título "Ultrajes a España", fueron interpretadas como una afrenta "al honor y a la integridad de la nacionalidad española ${ }^{67}$. En El Heraldo de Madrid se reproduce, a modo de desagravio, un artículo que había sido publicado en el Diario de Noticias de Lisboa, firmado por Caïel, pseudónimo de la escritora portuguesa Alice Pestana ${ }^{68}$. Otros se muestran irónicamente atónitos por no entender la relación entre la propaganda de una exposición y las "injurias a la mujer española y a Castilla, sus excitaciones a los portugueses para que se apoderen de Galicia, y demás muestras de patriotismo", y reproducen las palabras del discurso:

En la mujer catalana y en la portuguesa descubrimos el alma resignada, la persistencia en las afecciones, la esperanza y la sentimental tristeza en el hogar; la mujer catalana y la portuguesa tienen la conmovedora docilidad de la dulce compañera del hombre, que comparte, por amor infinito, pero tranquilo, que consagra sus dolores y sus alegría. Son mujeres de familia, del menage.

Contemplad, ahora, la mujer castellana que, aun cuando también cuidadosa y trabajadora, la veis adorablemente graciosa, elegante, risueña, como si la vida fuera para ella una senda florida, rindiendo un culto excesivo a la alegría comunicativa y afable, brillando con aires de reina en la soirée, en las corridas de toros, en el paseo y en la calle ${ }^{69}$.

Los periódicos de Barcelona vieron el asunto más sosegadamente ${ }^{70}$. Pero el causante del malentendido se vio obligado rectificar. Se justificó diciendo "que al hablar de la mujer castellana, como habló de la mujer catalana, la mujer portuguesa y la mujer gallega, lo hizo elogiándola, así en sus virtudes privadas, como en sus dotes sugestivas de mujer de sociedad y espíritu alegre y comunicativo", y atribuyó la tergiversación a "referencias inexactas" de la prensa lisboeta71.

\section{Cataluña apadrina a Galicia}

Billig ha observado que "cuando hoy día los presidentes estadounidenses afirman hablar al mismo tiempo en nombre de su nación y de un nuevo orden mundial, no están situando en la misma expresión, uno al lado del otro [...] están utilizando las posibilidades hegemónicas del nacionalismo"72.

Desde Cataluña se reivindicó tempranamente que todas las regiones de España habían de tener conciencia de si mismas, si se aspiraba a conseguir un país nuevo, no uniformado por lo castellano ${ }^{73}$. Con ello parecía decirse que el modelo catalán era equiparable a otros. Pero el afianzamiento del catalanismo no produjo, al menos para consumo interno, un imaginario visual de equiparación, sino de liderazgo, donde Cataluña se erigió en guía de los pueblos hispanos, en su proceso de liberación del yugo centralizador ${ }^{74}$.

Una de las facetas más interesantes de esta cuestión es la relación dual que, por razones específicas en cada caso, Cataluña establece con determinados territorios del mosaico español, una de cuyas piezas es Galicia. La singularidad del caso Galicia permite reconocer estrategias de seducción, oposición, complicidad y subordinación, atribuibles a cambios sociales y aspiraciones políticas.

En general, Barcelona, como capital de Cataluña, tiende a presentarse a si misma como una ciudad hospitalaria que se complace en agasajar a quien la vista. Los gallegos aparecen como destinatarios de esa buena acogida en una ilustración que lleva por título "Barcelona no es exclusivista" (Fig. 9), mensaje principal de

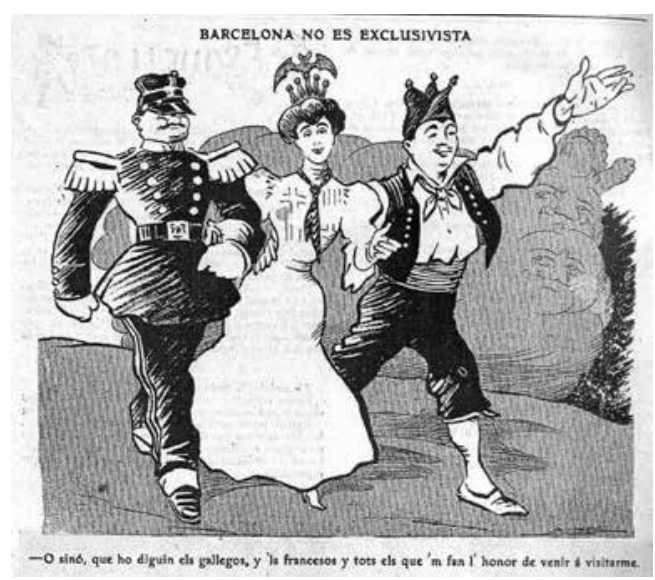

Fig. 9. Josep Costa Ferrer, Picarol, Barcelona no es exclusivista, L'Esquella de la Torratxa, 1907. 
la imagen ${ }^{75}$. En ella se ve a un gallego y a un francés que llevan del brazo a la doncella condal, un típico trío de la Belle Epoque. Está motivada por la simultánea presencia en la ciudad de una banda de regimiento de ingenieros franceses y de la rondalla gallega "Airiños d'a miña terra", procedente de Ferrol. Esta última visita tuvo una extraordinaria repercusión en la vida de la ciudad, según se recoge en la prensa: los gallegos

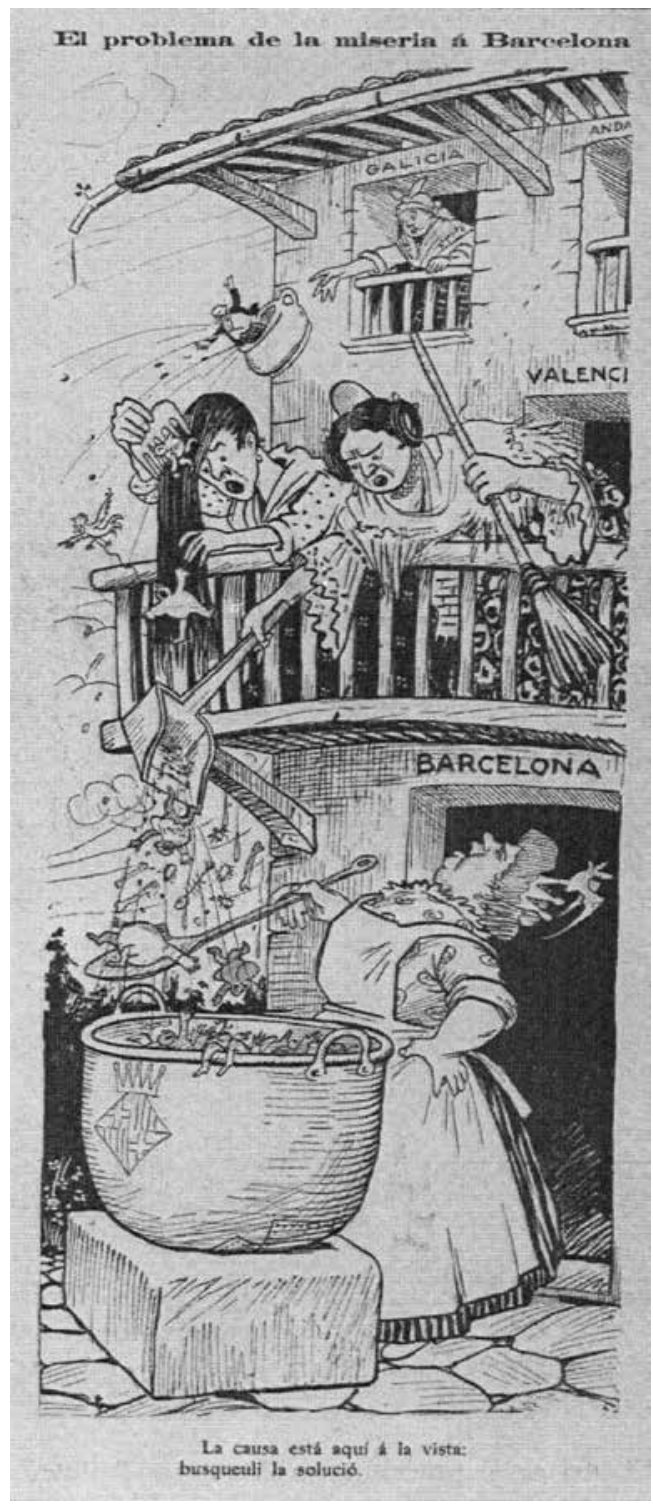

Fig. 10. El problema de la miseria en Barcelona, La Campana de Gracia, 1909. fueron espectacularmente recibidos en la Estación del Norte por una comisión del ayuntamiento y diversas entidades musicales, después de lo cual realizaron una ofrenda ante el monumento a Clavé y participaron en distintos en distintos festejos y actos, entre los cuales cabe destacar la visita al Ateneo catalanista de $\mathrm{Gracia}^{76}$, todo lo cual hace pensar que no fue un encuentro meramente folklórico, sino cargado de intencionalidad política.

La presentación de Cataluña o Barcelona como menospreciadas o agredidas por otras regiones o ciudades, salvo Madrid77, es rara. Lo habitual es el que el victimismo derive explícitamente de la prepotencia gubernamental española. Por eso resulta curiosa la ilustración que incluye La Campana de Gracia en 1909 con el título "El problema de la miseria en Barcelona" (Fig. 10), que lleva el siguiente pie: "La causa está aquí a la vista; buscadle la solución"78. En ella se ve a una Barcelona cocinera que tiene que soportar la basura que le arrojan los que viven encima, Valencia, primero, y Galicia, desde lo más alto. Parece que deba ponerse en relación con la falta de apoyos de los republicanos de Valencia a la política de Lerroux. Aunque en la asamblea republicana de hacen constar "las simpatías de Galicia para Cataluña"79 en la olla que arroja Galicia se reconoce la caricatura del Emperador del Paralelo.

Esas simpatías gallegas hacia Cataluña habían "surgido" dos años antes, tras las visitas de los diputados de Solidaritat a Galicia en 1907,

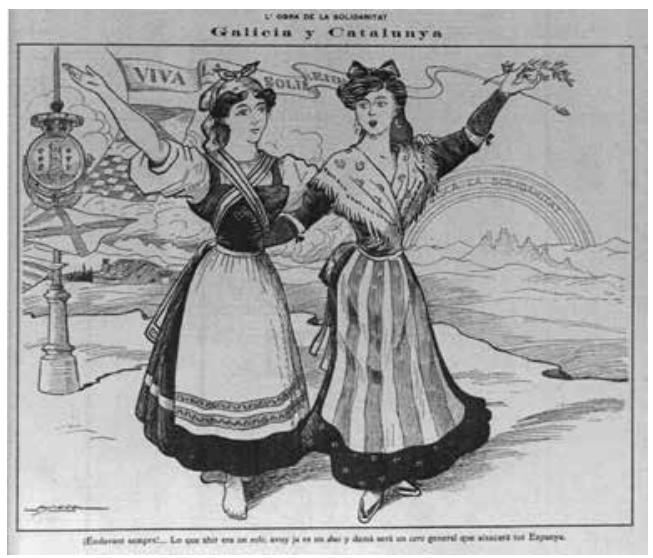

Fig. 11. Josep Costa Ferrer, Picarol, Galicia y Cataluña, La Campana de Gracia, 1907. 


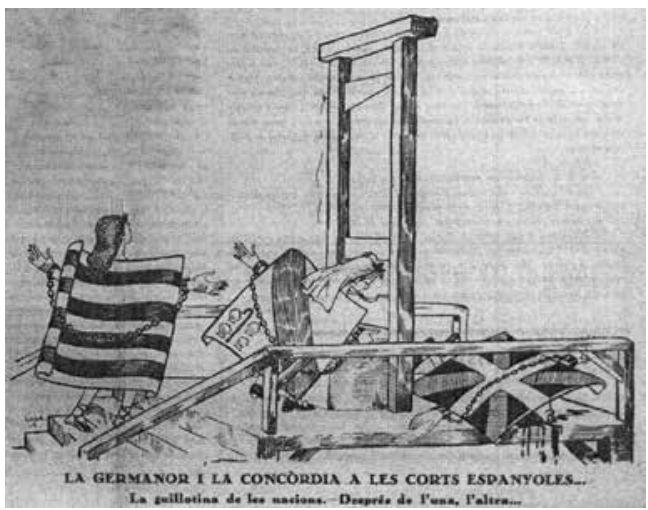

Fig. 12. Lola Anglada i Sarriera, La hermandad y la concordia en las Cortes Españolas, Nosaltres sols!, 1931.

cuya recepción se interpretó como el germen de una ola nacionalista que se extendería por todas partes $^{80}$. En una ilustración coetánea (Fig. 11) aparecen las personificaciones de Galicia y Cataluña, como dos muchachas jóvenes, vestidas con sus respectivos trajes regionales, felizmente unidas por el mismo destino: " ¡Adelante siempre!... lo que ayer era un solo, hoy ya es duo

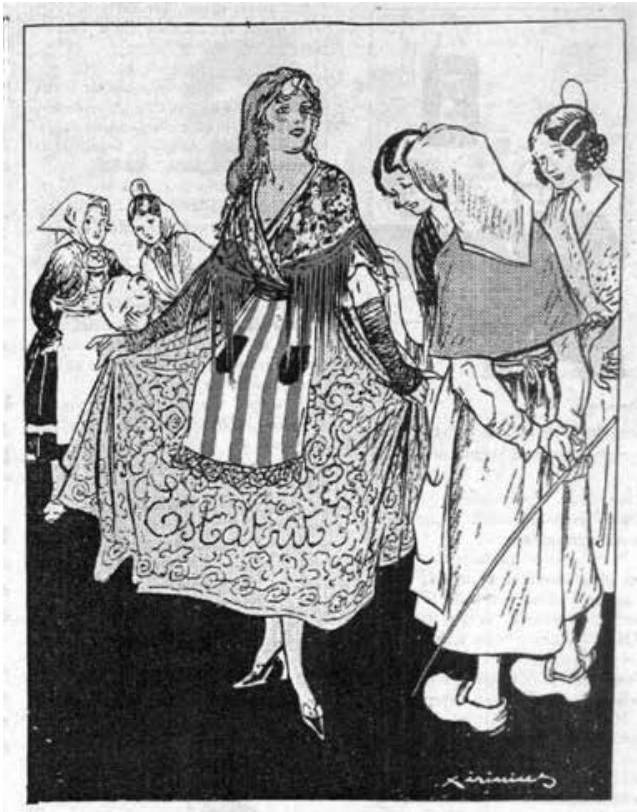

El vestit nou de l'Estatut

iLes altres regions:-Fas molt goig; nosaltres tambe denanarem un vestit nou,

Fig. 13. Jaume Juez i Castellà, Xirinius, El vestido nuevo del Estatuto, L'Esquella de la Torratxa, 1932.

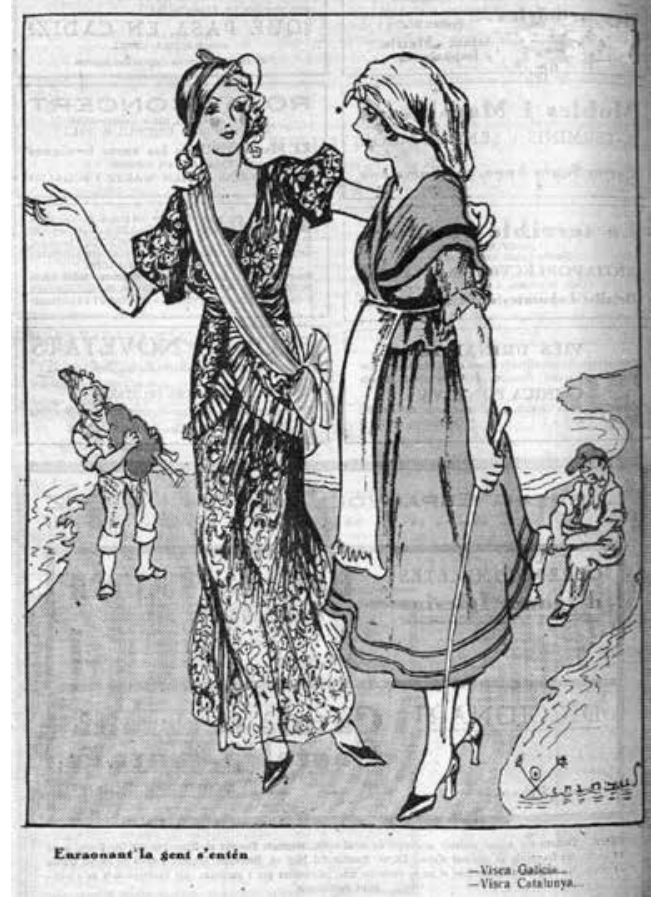

Fig. 14. Jaume Juez i Castellà, Xirinius, Hablando se entiende la gente, L'Esquella de la Torratxa, 1932.

y mañana será un coro general que levantara toda España"81. Galicia -con los pies desnudos, mientras Cataluña gasta alpargatas de payesaaparece, pues, como el primer eslabón de un proceso.

En la Galicia de los años veinte se oía decir, al parecer, que "Galicia necesitaba regalleguizarse catalanizándose" 82 , aunque hasta la Segunda República no se iniciaría el proceso estatutario. Cuando todavía se elaboraba la Constitución Republicana, a mediados del año 1931, Nosaltres sols!, portavoz de un catalanismo radical, atacaba con indignación las presiones del castellanismo centralista para condicionar la elaboración de los futuros estatutos. Una ilustración imagina al País Vasco, Galicia y Cataluña, personificadas por este orden, que caminan hacia la guillotina: "La hermandad y la concordia en las Cortes Españolas. La guillotina de las naciones. Después de una, otra"83 (Fig. 12).

La inminente aprobación del estatuto catalán en 1932 hizo revivir el papel de faro que ocupaba Cataluña ante las otras regiones, envi- 
diosas del "vestido nuevo" que estaba a punto de estrenar Cataluña, según se recoge en una ilustración. Aunque ese vestido mantiene los elementos más característicos del traje regional, como la gandalla, que recoge el pelo, y los mitenes, que cubren los brazos, Cataluña no destaca tanto por eso, sino por sus elegantes zapatos de tacón, más propios de una chica urbana que de una pubilla pueblerina, mientras Galicia, a su lado, todavía gasta zuecos ${ }^{84}$ (Fig. 13).

Esta superioridad se acentúa en otra ilustración aparecida poco después, donde una estilizada y elegante Cataluña, vestida con un traje largo de fiesta, que no conserva más signo de identidad nacional que la banda, acoge efusivamente a una cauta Galicia, todavía con el traje regional, a la que parece decir, según consta al pie: "Hablando se entiende la gente"85 (Fig. 14). Al menos Galicia ya lleva zapatos de tacón. En el calzado se aprecia un claro progreso.

Estas imágenes son bien elocuentes de la necesidad que tienen los imaginarios nacionalistas de contar con el otro para definirse a si mismos. Aunque su caracterización está condicionada por estrategias de poder, tras la que se esconden discursos de clase o prejuicios de género, la alegoría cumple su función de contribuir a legitimar aspiraciones políticas. El derecho a defenderlas con palabras no basta. La personificación visual ajena termina por provocar una identificación con una causa, que es la propia, porque el otro siempre se construye a partir de las carencias de uno mismo.

\section{NOTAS}

Este trabajo se ha realizado dentro del proyecto de investigación "La invención de la ciudad: memoria, visualidad y trasferencia cultural en la Barcelona contemporánea" (HAR2013-42987-P)

2 M. Billig, Nacionalismo banal, Capitán Swing Libros, Madrid, 2014, p. 18

${ }^{3}$ J.M. Fradera, Cultura nacional en una sociedad dividida. Cataluña, 18381868, Marcial Pons, Madrid, 2003, p. 60.

4 Son clásicos los estudios de M. Agulhon: Marianne au combat. L'Imagerie républicaine de 1789 à 1880, Flammarion, París, 1979; Marianne au pouvoir. L'imagerie et la simbolique republicaines de 1880 à 1914, Flammarion, París, 1889; Les métamorphoses de Marianne. L'imagerie et la symbolique républicaines de 1914 à nos tours, Flammarion, París, 2001; y, con P. Bonte, Marianne. Les visages de la République, París, Gallimard, París, 1992.

${ }^{5}$ He abordado esta cuestión de la coexistencia de personificaciones en algunos trabajos anteriores, el más reciente Monarquía y Romanticismo. El hechizo de la imagen regia, 18291873, Siglo XXI, Madrid, 2015.
${ }^{6}$ Véanse, entre otros, los trabajos de F. Espinet i Burunat, Notícia, Imatge, Simulacre. La recepció de la societat de comunicació de masses a Catalunya de 1888 a 1939, UAB, Barcelona, 1997; y "La Solidaritat Catalana i la premsa gràfica" en Solidaritat catalana i Espanya (G. Rubí y F. Espinet, comp.), Editorial Base, Barcelona, 2008, pp. 223-235. También las monografías publicadas por la editorial Efadós, que incluyen estudios específicos, sobre CuCut! (2012), L'Esquella de la Torratxa (2013) o Papitu (2014), coordinadas por J. Capdevila.

7 Es fundamental la investigación llevada a cabo por R. E. McGlade, Seriously Funny: Towards an Interpretative Framework for an Analysis of Catalan Satirical Cartoons in the Twentieth Century, University of Sheffield, 2013 [Tesis Doctoral].

${ }^{8}$ B. Anderson, Comunitats imaginades, Afers, Valencia, 2005, p. 54

${ }^{9}$ A. Duprat, "La caricature, médiatrice de la figuration de la République autour de 1830", en M. Agulhon, A. Becker y É. Cohen, La République en représentations. Autour de l'oevre de Maurice Agulhon, París, Sorbonne, 2006, p. 184.

${ }^{10} \mathrm{H}$. Belting, Antropología de la imagen, Katz, Madrid, 2007, pp. 71 y ss.
${ }^{11}$ E. Ucelay da Cal, El Imperialismo catalán, Prat de la Riba, Cambó, D’Ors y la conquista moral de España, Edhasa, Barcelona, 2003, pp. 31-33.

12 K.M. McGraw y T. M. Dolan, "Personifying the State: Consequences for Attiude Formation", Political Psychology, t. 28, n 3, 2007, pp. 299327.

13 Por ejemplo, en Fray Gerundio (19 de octubre de 1837) ya encontramos a doña Hispanita, doña Francesina y doña Britania jugando a las cartas (J. Capdevila, "La figura femenina en la prensa satírica española del siglo XIX", Historietas, 2, 2012, p. 21).

${ }^{14}$ Especialmente elocuente es un cartel anunciador del veraneo en Hendaya (ca. 1990), donde una rubia vestida a la moda burguesa, que representa a una sofisticada Francia, se inclina para recibir a una morena, más popular y humilde España (L. Sazatornil y A. B. Lasheras Peña, "París y la españolada. Casticismo y estereotipos nacionales en las exposiciones universales (18551900)", Mélanges de la Casa de Velázquez. Nouvelle série, 35 (2), 2005, pp. 265-290. Las relaciones entre España y algunos estados de América, por ejemplo Estados Unidos, con motivo de la guerra de Cuba, y Argentina, con motivo de las celebraciones de la independencia, produjeron imágenes bien cu- 
riosas. Algunos ejemplos en: C. Reyero, "España repiensa América: la conmemoración de la hispanidad en torno al centenario", en Balances, perspectivas y renovaciones disciplinares de la historia del Arte, Centro Argentino de Investigadores de Arte, Buenos Aires, 2010, pp. 299-310; J. Moreno Luzón y R. Rodríguez Viñuales (eds.), Memorias de la independencia. España, Argentina y México en el primer centenario (19081910-1912), Acción Cultural Española, Madrid, 2012.

${ }^{15} \mathrm{~S}$. Jacobson, "Identidad nacional en España, el Imperio y Cataluña: Una perspectiva comparativa", en Pueblo y Nación. Homenaje a José Álvarez Junco (J. Moreno Luzón y F. del Rey, eds.), Taurus, Madrid, 2013, p. 263. Para el caso de España, véanse, entre otros: $F$. Archilés y M. Martí, "La construcció de la regió com a mecanisme nacionalitzador i la tesi de la dèbil nacionalització espanyola, Afers. Fulls de Recerca i Pensament, t. 19, n 48, 2004, pp. 265-368; y "Una nació fracassada? La construcció de la identitat nacional espanyola al llarg del segle XIX", Recerques. Històrica, Economia i Cultura, t. 51, 2005, pp. 141-163.

${ }^{16}$ Además de la conocida expedición de poetas y dramturgos catalanes a la Provenza, en la prensa se visualizan las relaciones entre Francia y Cataluña - Barcelona (por ejemplo con motivo del salón de París en 1917) o con Génova, como motivo de la inauguración del monumento a Colón, entre otros.

17 J.M. Fradera, Cultura nacional... op. cit, p. 36.

18 J. Fontana, La formación d'una identitat. Una història de Catalunya, Eumo Editorial, Barcelona, 2014, p. 315.

19 J. M. Fradera, "El proyecto liberal catalán y los imperativos del doble patriotismo", Ayer, t. 35, 1999, pp. 97-98.

20 "Patriotismo quejumbroso" ha sido denominado por J. Álvarez Junco, Mater Dolorosa. La idea de España en el siglo XIX, Taurus, Madrid, 2001.

21 "Es difícil encontrar un adjetivo que defina La Tramontana: catalanismo, republicanismo, librepensamiento, masonería, anarquismo y anticlericalismo se dan cita en sus columnas". M. Vicente i Izquierdo, "La Tramontana
(1881-1896), periòdic vermell escrit en català", Gazeta, 1, 1994 , p. 373.

22 Almanac de la Tramontana, 1896, s.p. [en catalán en el original]

${ }^{23}$ Recogido por E. Ucelay, El Imperialismo catalán op. cit., p. 90.

${ }^{24}$ En la masonería es frecuente el carácter dual de los símbolos y las imágenes dobles. Véase: J.C. Daza, Francmasonería, Akal, Madrid, 1997, pp. 122 y 352 .

${ }^{25} \mathrm{M}$. Comas y M. Rosich, Surge et Ambula. 125 Anys de Biblioteca Museu, OALP Víctor Balaguer, 1999, s.p.

${ }^{26}$ F. Quílez, "El temple-taller Masriera: un model singular d'atelier vuitcentista", en Els Masiera (Cat. Exp.), Generalitat de Catalunya, Barcelona, 1996, pp. 162-172.

${ }^{27}$ Discursos leídos antes la Academia de Bellas Artes de San Fernando en la recepción pública del Sr. D. Francisco Sans el día 29 de junio de 1875, Madrid, 1875, p. 18. No son, por cierto, las figuras de Fortuny y Rosales las únicas que sugieren este dualismo: es significativo que junto a los nombres castellanos de los escritores José de Espronceda y Mariano José de Larra y los actores Julián Romea y Carlos Latorre, mencione a los catalanes Ramón Carnicer y Ramon Vilanova, y, sobre todo, que, en escultura el nombre de José Álvarez Cubero se corresponda con el de Antoni Sola (Ibídem, p. 46)

${ }^{28}$ La llustración Artística, 7 de julio de 1884, p. 218 . La vista del edificio y las estatuas se reproducen en pp. 222 y 223.

29 La llustració Catalana, 15 de septiembre de 1884 , t. V, p. 259 [en catalán en el original]

${ }^{30}$ La llustració Catalana, 15 de septiembre de 1884 , t. V, p. 362 [en catalán en el original]

31 F. Fontbona, "la llustración gráfica. Las técnicas fotomecánicas", en El grabado en España, siglos XIX-XX (J. Carrete y otros), Espasa-Calpe, Madrid, 1988, p. 465 [Reproducida en p. 466]. Apareció publicada en L'Esquella de la Torratxa, 17 de junio de 1898. Fue concebida por Manel Moliné i Muns (Barcelona, 1833-1901).

${ }^{32}$ Con el título "Propaganda, parodia, imagen de marca. La metamor- fosis gráfica del monumento a Colón de Barcelona entre dos grandes exposiciones, 1888-1929" fue presentada en el encuentro internacional El arte público a través de la documentación gráfica y literaria, Institución Fernando el Católico, Zaragoza, 4-7 de noviembre de 2014 [en prensa].

${ }^{33}$ La llustración Catalana, 15 de octubre de 1892.

${ }^{34}$ E. Ucelay, El Imperialismo catalán op. cit, pp. 442-443.

${ }^{35}$ La Campana de Gracia, 22 de enero de 1898 [en catalán en el original]

${ }^{36} \mathrm{~J}$. M. Fradera, "El proyecto liberal catalán", op. cit., p. 87; A. Colomines i Companys, "El catalanismo político de fines del siglo XIX y principios del XX. El proyecto regeneracionista para España", en Cataluña-España. Relaciones político-culturales (X. Antich; A. Castiñeira; J. Colominas), Icaria Editorial, Barcelona, 2003, pp. 22 y ss.

${ }^{37}$ Por ejemplo: "Nacer en tierras castellanas y ser tonto de solemnidad es una misma cosa" [en catalán en el original] (J. LL. Marfany, La cultura del catalanisme. El nacionalisme català en els seus inicis, Editorial Empúries, Barcelona, 1995, p. 206).

${ }^{38}$ A. Duarte, "España desde Cataluña. Cepas de una apreciación de largo alcance", en Historia de la nación y del nacionalismo español (A. Morales Moya; J.P. Fusi Aizpurúa y A. De Blas Guerrero, dirs.), Galaxia Guenberg, 2013, p. 952.

${ }^{39}$ En ese sentido, en Cataluña es más habitual la oposición entre lo catalán y lo español (visualmente construido de distintos modos, desde luego) que el enfrentamiento con otros "entes regionales", a diferencia de los que sucedió en Galicia en el siglo XIX, por ejemplo. Véase: J. Beramendi, "Algunos aspectos del nation-building español en la Galicia del siglo XIX", en Construir España. Nacionalismo español y procesos de nacionalización (J. Moreno Luzón, ed.), Centro de Estudios Políticos y Constitucionales, Madrid, 2007, pp. 53-53. Del mismo autor: "Imágenes y funciones de Castilla en la construcción de la historicidad de Galicia", en ¿Alma de España? Castilla en las interpretaciones del pasado es- 
pañol, Marcial Pons, Madrid, 2005, pp. 271-297.

${ }^{40}$ Aparece en un recorte de prensa, que lleva a lápiz la fecha del 9 de noviembre de 1873, recopilado en: T. Padró i Pedret, Caricatures politiques dels anys 1869 a 1872 (col/leció formada per Ferran de Segarra), Barcelona, Biblioteca de Catalunya, Àlbum G Fol 15. En aquel año se publicaron imágenes similares en la prensa satírica, como el pulso que echan la república unitaria y la federal (La Campana de Gracia, 16 de marzo de 1873). Sobre la influencia francesa en esta iconografía: M.-A. Orobon, "Marianne y España. La identidad nacional en la Primera República española", Historia y Política. Ideas, procesos y movimientos sociales, $n^{\circ} 13$, 2005, pp. 79-98.

${ }^{41}$ Lo que el catalanismo rechazaba era "el concepto de una España forjada por y desde Castilla", lo que colisionaba con la mayoría de los liberales e intelectuales radicados en Madrid, para quienes esa cuestión era tan evidente como incuestionable (B. de Riquer i Permanyer, Escolta, Espanya. La cuestión catalana en la época liberal, Marcial Pons, Madrid, 2001, pp. 106 y 207).

${ }^{42}$ E. Ucelay da Cal, "El catalanismo ante Castilla o el antagonista ignorado", en ¿Alma de España?... op. cit., pp. 221

${ }^{43}$ S. Jacobson, "Identidad nacional en España", op. cit., p. 279 [con bibliografía anterior].

${ }^{44}$ A. Colomines i Companys, "El catalanismo político de fines del siglo XIX y principios del XX. El proyecto regeneracionista para España", en Cataluña-España. Relaciones político culturales (X. Antich; A. Castiñeira; J. Colominas, eds.), Icaria Editorial, Barcelona, 2003 , p. 37

45 E. Roa White, "The Four Mothers of the Dispossessed: Motherhood in Irish Melodies and Cantares Galegos," en (M)othering the Nation: Constructing and Resisting Regional and National Allegories Through the Maternal Body (Lisa Bernstein, ed.), Cambridge Scholars Publishing, Newcastle, 2008, pp. 23-35.

46 J. Beramendi González, "Visiones gallegas de Castilla", "en Castilla y
León en la historia contemporánea (M. Redero San Román y M.D. de la Calle Velasco, eds.), Ediciones Universidad de Salamanca, Salamanca, 2008, p. 119

${ }^{47}$ P. Anguera Nolla, "La visión de Castilla desde Cataluña. Algunas opiniones", en Castilla y León en la historia contemporánea op. cit., p. 88.

${ }^{48}$ Cu-Cut, 25 de agosto de 1904, p. 546 [en catalán en el original]. Lleva la firma de Gaietà Cornet i Palau (Barcelona, 1848-1945)

49 J. Pinyol Vidal, "Iconografia del catalanisme insolent", en Cu-Cut!. Sàtira política en temps trasbalsats (1902-1914) (J. Capdevila, coord.), Efadós, Barcelona, 2012, p. 65 [en catalán en el original]

${ }^{50}$ El Heraldo de Madrid, 20 de junio de 1907.

${ }^{51}$ Gedeón, 23 de junio de 1907. Lleva la firma de Sileno, pseudónimo de Pedro Antonio Villahermosa Borao (Zaragoza, 1869-Madrid, 1945). La expresión iTaday, probeza!, extraída del habla popular montañesa, aparece en la novela de José María de Pereda El sabor de la tierruca. Es el resultado de una contracción, taday por quita de ahí, y una metátesis, probeza, en lugar de pobreza. Se utiliza con alguna frecuencia en el periodismo de la época con el sentido iQué me venís a contar a mí!

52 N. Yuval-Davis, Gender and Nation, Londres, Sage Publ., 1997, pp. 46 y ss.

53 Como se sabe, una forma de manifestar la superioridad moral de la nación propia se realiza mediante el énfasis en la virtud y en la castidad, frente a la permisividad sexual que hay fuera. La cuestión ha sido tratada en numerosos trabajos, sobre todo en relación con el orientalismo, entre otros: L. Nochlin, "The Imaginary Orient", en The politics of vision: essays on nineteenth Century art and society, Harper \& Row Nueva York, 1989, pp. 33-59; R. Lewis, Race, Feminity and Representation, Routledge, Londres, 1996; J. Hacforth-Jones y M. Roberts (eds.), Edges of Empire. Orientalism and Visual Culture, Blackwell, Malden, 2005. También en la visión de los Estados Unidos sobre Latinoamérica: J. Burton, "Don (Juanito) Duck and the Imperial-Patriarchal Un- conscious: Disney Studios, the Good Neighbor Policy, and the Packaging of Latin America", en Nationalisms and Sexualities (A. Parker et alii, eds.), Routledge Nueva York, , 1992, pp. 21-41.

${ }^{54} \mathrm{I}$. Blasco Herranz, "Mujeres y nación: se españolas en el siglo XX", en Ser españoles. Imaginarios nacionalistas en el siglo XX (J. Moreno Luzón y X. M. Núñez Seijas, eds.), Barcelona, RBA, 2013, p.168 [con bibliografía].

55 Abordé algunos aspectos de esta cuestión en: "Patria, una mujer tan femenina, un amor tan masculino" en Mirando a Clio. El arte español, espejo de su historia. Actas del XVIII CEHA, Universidad, Santiago de Compostela, 2012, pp. 2136-2158. Sobre género nacionalidad véase, con bibliografía: N. Aresti, "Masculinidad y nación en la España de los años 1920 y 1930", en Género, sexo y nación: representaciones y prácticas políticas en España (siglos XIX-XX), Mélanges de la Casa de Velázquez, t. 42-2, 2012, pp. 55-72.

${ }^{56}$ La llustració llevantina. Revista artistich-literaria de Catalunya, Valencia, Mallorca y Rosselló, 1900, 2, p. 32 [en catalán en el original]. Este imaginario tiene su plasmación en numerosas pinturas catalanas del cambio de siglo.

57 J.M. Gabriel y Galán, Antología poética, Castalia, Madrid, 2001, p. 69

${ }^{58}$ La Tralla, 15 de enero de 1907 [en catalán en el original]

59 Ibidem [en catalán en el original]. Véase también: J. Laínz, España contra Cataluña. Historia de un fraude, Ediciones Encuentro, Madrid, 2014, p. 177

${ }^{60}$ La Época, 18 de enero de 1907

61 El Heraldo de Madrid, 18 de enero de 1907.

62 El Globo, 20 de enero de 1907.

${ }^{63}$ El País, 20 de enero de 1907. La republicana y feminista Consuelo Álvarez Pool, nacida en Barcelona, utilizaba ese pseudónimo.

${ }^{64}$ L'Esquella de la Torratxa, 25 de enero de 1907 [en catalán y en cursiva en el original]. Lleva la firma de L. Alegre.

${ }^{65}$ Así lo sostiene en su libro Portugal y Galicia nación. Identidad étnica, 
histórica, literaria, filológica y artística, Tobella, Barcelona, 1911

${ }^{66}$ El año político, 1907, p. 112.

${ }^{67}$ La Correspondencia Militar, 4 de abril de 1907.

${ }^{68}$ El Heraldo de Madrid, 16 de abril de 1907.

${ }^{69}$ El Imparcial, 12 de abril de 1907.

${ }^{70}$ La Vanguardia, 5, 6 y 17 de abril de 1907, p. 2.

${ }^{71}$ La Época, 18 de abril de 1907. Eso no impidió que apareciera un pasquín en la fábrica de tabacos, animando a las cigarreras a que se manifestaran en acto de protesta, junto a los estudiantes, en el hotel en el que se hospedó en Madrid, que salió de inmediato para Guadalajara, donde tomó el expreso de Barcelona (La Correspondencia de España, 19 de abril de 1907)

72 M. Billig, Nacionalismo... op. cit., p. 109

73 "Queremos hermandad de todas las regiones españolas y buscamos la manera de ahorrarnos muchas lágrimas y desengaños, mientras que el unitarismo está convirtiéndolas en una nación de escépticos", escribió el historiador fuerista Josep Coroleu (Recogido por E. Ucelay, El Imperialismo catalán op. cit., p. 313)

74 Las imágenes concebidas para popularizar una política descentralizadora, fueron numerosas, tanto en tarjetas postales como en prensa gráfica. En una de Solidaritat Catalana, de 1906, la matrona Cataluña "se dirige a una multitud de regiones masculinas ávidas de orientación" (E. Ucelay, El Imperialismo catalán op. cit. lámina fuera de paginación, antes de la p. 554). Es más frecuente que sean figuras femeninas diferenciadas por sus trajes regionales, a veces, acompañadas de sus nombres, para una mejor identificación. Por ejemplo, en la publicada en La Campana de Gracia el 18 de Mayo de 1907, Cataluña, a las puertas del "Hostal de la Solidaritat", dice a las otras regiones, entre las que se reconoce a Galicia, en último término, tras Vascongadas [sic]: "¡Venid, hermanas, venid! Aquí cabéis todas".

${ }^{75}$ La Campana de Gracia, 5 de julio de 1907. Lleva la firma de Picarol, pseudónimo de Josep Costa Ferrer (Ibiza, 1876-Palma, 1971).

${ }^{76}$ La Vanguardia recoge numerosa información a lo largo de todo el mes de junio de 1907, especialmente a partir de su llegada el día 23.

${ }^{77}$ C. Reyero, "'La vila de l'ós i las ciutat dels comtes'. La visualización de Madrid en los orígenes del nacionalismo catalán", VI Jornadas Arte y Ciudad, Madrid, 1,2 y 3 de abril de 2014, Facultad de Ciencias de la Información, Universidad Complutense de Madrid [en prensa]

${ }^{78}$ La Campana de Gracia, 17 de junio de 1909.
${ }^{79}$ La Vanguardia, 28 de junio de 1907

80 En la prensa de Madrid, en cambio, las hipótesis sobre las posibles consecuencias son ambiguas o descreídas. Véase, entre otros: La llustración Española y Americana, 15 de octubre de 1907, p. 218; El Siglo Futuro, 11 de octubre de 1907; o El Imparcial, 12 de octubre de 1907.

${ }^{81}$ La Campana de Gracia, 5 de octubre de 1907 [en catalán en el original]. Firmada por Picarol.

82 J.M. Ribera Llopis y O. Rodríguez González, "Crisi finisecular en la cultura gallega: atenció al model català", en 1898. Entre la crisi d'ldentitat i la modernització. Actes del Congrés internacional celebrat a Barcelona 2024 d'abril de 1998, Publicacions de l'Abadia de Montserrat, Barcelona, 2000, t. I, p. 249

${ }^{83}$ Nosaltres sols!, 3 de octubre de 1931 [en catalán en el original]. Lleva la firma de Lola Anglada i Sarriera (Barcelona, 1892-Tiana, 1984).

${ }^{84}$ L'Esquella de la Torratxa, 13 de mayo de 1932 [en catalán en el original]. Lleva la firma de Xirinius, pseudónimo de Jaume Juez i Castellà (Barcelona, 1906-Aranjuez, 2002).

85 L'Esquella de la Torratxa, 29 de julio de 1932 [en catalán en el original]. También fue realizada por Xirinius. 